\title{
Health Benefits of Nutritive Value and Qualitative Symptoms in Okra (Abelmoschus Esculentus): A Review
}

\author{
Tanu Shiri* \\ Department of Genetics and Plant Breeding, \\ CCS University campus, Meerut-250004 (UP) \\ India \\ Shailendra S. Gaurav \\ Department of Genetics and Plant Breeding, \\ CCS University campus, Meerut-250004 (UP) \\ India

\section{S.K. Singh} \\ Department of Genetics and Plant Breeding, \\ CCR (PG) College, Muzaffarnagar-251001 (UP) \\ India
}

\author{
Arvind Kumar \\ Department of Genetics and Plant Breeding, \\ CCS University campus, Meerut-250004 (UP) \\ India \\ Swati Sharma \\ Department of Bioscience, \\ Vinayak Vidyapeeth Modipuram, Meerut-250001 (UP) \\ India \\ Shrashti Teja \\ Department of Bioscience, \\ Vinayak Vidyapeeth Modipuram, Meerut-250001 (UP) \\ India
}

\begin{abstract}
Economically significant crop (okra) are cultivated in humid area of the world. It is a versatile crop due to various uses of fresh leaves, buds, pods, steam and seeds but it can be another used in vegetable, salads, soups, etc. In medicinal applications on okra mucilage replacement of plasma or volume of blood are being used as expanders. Toxins carrying harmful atoms in human body are discarded by the liver in which the okra's mucilage bound atoms of cholesterol and bile juice. It is a powerhouse of valuable nutrients, it is soluble fiber in the form of latexes and pectin that helps to decrease serum cholesterol, thereby reducing the risk of type 2 diabetes, cardiovascular, digestive, some cancers diseases and insoluble fiber helps to keep intestine healthy. Study the asymmetry for fruit production and manage its contribution to the characters performing at the middle value of parents for most symptoms and to better display significant and positive asymmetry on parents. Inequality on better parents per plant was mainly due to long and coarse fruits with higher yield of fruits per plant.
\end{abstract}

Keywords: Okra, cholesterol and oil.

\section{INTRODUCTION}

Member of Malvaceae like okra is one of the cultivated in sub-tropical regions. It is a proficient source of vitamins, proteins, carbohydrates, saccharides, minerals, iron and iodine (Diaz and Ortegon, 1997). India with four hundred ninety thousand hectares and five million seven hundred eighty thousand tonnes accounted for $47.2 \%$ of the world acreage and $73.9 \%$ production of okra during 2011 (FAO Stat database, 2011). Seed of Okra is also a rich source of linoleic acid that is polyunsaturated fatty acids needed for human nutrition. It has been commercially cultivated in various states of India (Uttar Pradesh, Gujarat, Maharashtra, Andhra Pradesh Karnataka and Tamilndu for many years. As such around is a requirement to increase the yield per unit area to achieve the improvement of production from a limited field in India. India occurring 10 species of
Abelmosus only A. esculentus is known to be in cultivation with maximum phenotypic variability. Immature pods of okra are used in making pickles and used for many meals (Madison, 2008; Maramag, 2013). Important indigenous diversity occurs in okra for plant height, hairiness, branching, pigmentation, fruit characters and their reaction to biotic stress and abiotic stress (Dhankhar et al., 2005). Very tall, healthy, purple pigmented, tolerant to cold and late maturing types occur in the high-altitude tribal areas in the Peninsular plateau (Pandravada et al., 2004).

Seed of okra to be rich in high quality of protein, specially to the content of crucial amino acid comparative to other plants. Improve the yield of okra significantly through intensive and concerted breeding efforts and another advanced yield to be more problematic demanding the use of new breeding styles. The essential aim of production increases in the fastest possible time can be completed only through heterosis breeding, which is practical in this crop (Vijayraghvan and Warier, 1946). In current time most, important development in plant breeding programs has been the use of heterosis or hybrid. The phenomenon of asymmetry has been a powerful force in plant growth and has been extensively exploited in crop production of okra. The scope of use of asymmetry largely depends on the direction and magnitude of the asymmetry (Birchler et al., 2003).

Heterosis is articulated as comparative heterosis and heterobeltiosis reliant on the measures used to associate the performance of a hybrids. It is the dominance of hybrid over its mid parental value (related heterosis) or over its best parents (heterobeltiosis) or over analysis the standard, commercial (marketable production), economic heterosis. In various cases, F1 hybrids have been found out-yielding their parents or predominant local commercial best varieties used as analyzed. The comparable heterosis will only usable to 
understand the genetic status of the characters (Moll and Stuber 1974). Until now, from the research and economic point of view, standard heterosis is the mostly significant of 3 types of heterosis since it is aimed at developing desired hybrids superior to the existing highly yield edible commercial varieties (Chaudhary,1984). Its reproduction is important genetic tool, it can facilitate yield growth by 30 $400 \%$ and help enrich many other desirable qualitative and quantitative traits in crops (Srivastava, 2000). Complete irregular reproduction, it is often possible to add the wanted island to the regular method without waiting for a long time in terms of development of cross-pollinated cultivation.

The valuation of hybrid show for traits of interest is a main aim for breeders trial to develop new best varieties, as this help is collection the best parental varieties crosses and reduces the essential of cost and less time consuming trials (Agarwal,1998). This inspires studying the heterosis from a wide collection of parental combination of best cross. The present research goal to regulate the performance and heterotic design between the $10 \times 10$ half dialele cross, which identified hybrids with better hybrid enthusiasm for yield and its mechanism of okra.

\section{COMPOSITION OF NUTRITIVE VALUE IN OKRA}

Okra is mostly used as dietary vegetable and its seed have been used for oil production (National Research Council, 2006). Lipid components contribute greatly to almost different types of foods or the nutritional and sensory value of nature that provide high amount of good fat that different in their chemical and functional properties. Composition of Fatty acid are lipids (triacylglycerol, diacylglycerol, polar lipids and free fatty acids) mostly triacylglycerols are naturally lipid storage compound that compared unsaturated and saturated fatty acid that differ in length of their acyl chain and the number and position of saturated fatty acid. Monoenoic like double bond and polyunsaturated fatty acid that have extensive fatty acids and different in relation to composition. Monoenoic fatty acids and polyunsaturated fatty acid are structurally isolate from the existence of a repetition of methylene unit and potential source of Greece or oil production from seeds of okra, in which concentration vary $20-40 \%$ to the extraction method (Sorapong, 2012; MEF, 2013). The characteristic of biological value is the ratio of their digestive capacity protein and amino acid content (Ewa, 2011). A perfect villager's vegetable (okra) present in fiber, balance protein, lysine and tryptophan (Holser \& Bost, 2004; Sanjeet et al., 2010).

The $1000 \mathrm{mg}$ appetizing leaves of okra composition is protein $4,400 \mathrm{mg}$, fat $600 \mathrm{mg}$, carbohydrate $11,300 \mathrm{mg}$, water $81,500 \mathrm{mg}$ energy $235.00 \mathrm{~kJ}$, fiber $2,100 \mathrm{mg}$, Ca $532.00 \mathrm{mg}$, P $70.00 \mathrm{mg}$, Fe $0.70 \mathrm{mg}$, ascorbic acid $59.00 \mathrm{mg}$, thiamin $0.25 \mathrm{mg}$, riboflavin $2.80 \mathrm{mg}$, niacin $0.20 \mathrm{mg}$ and $\beta$ carotene $385 \mu \mathrm{g}$. Fresh pod of okra contain low calories (20/100 gm), vitamin C 16-29 mg, folate 46-88mg and Vitamin A (14-20 mg). The $1000 \mathrm{~g}$ edible part pods of okra configuration is protein $2 \mathrm{~g}$, carbohydrate $8 \mathrm{~g}$, fat $0.2 \mathrm{~g}$, water $88 \mathrm{~g}$, energy $144 \mathrm{~kJ}$, fiber $1 \mathrm{~g}, \mathrm{Ca} 84 \mathrm{mg}, \mathrm{P} 90 \mathrm{mg}$, Fe $1.20 \mathrm{mg}$, ascorbic acid $47.00 \mathrm{mg}$, thiamin $0.04 \mathrm{mg}$, riboflavin $0.08 \mathrm{mg}$, niacin $0.60 \mathrm{mg}$ and $\beta$-carotene $185 \mu \mathrm{g}$ (Gopalan et al., 2007; Varmudy, 2011). Young fruit of okra contain long chin molecule with high molecular weight $(170,000)$ made of sugar unit, amino acid and main component are galacturonic acid $(27 \%)$, galactose $(25 \%)$, rhamnose (22\%), amino acid (11\%) and mucilage $30 \%$. K, $\mathrm{Na}, \mathrm{Mg}$ and $\mathrm{Ca}$ are major element in pods, which contain $17 \%$ seeds and also contain $\mathrm{Zn}, \mathrm{Mn}, \mathrm{Fe}$ and Ni (Moyin-Jesu, 2007)

In Northern America were collected 3-7 cm size of pods for commercially harvested .Small size pod contain high nutritive value according to genotypic study (Petropoulos, et al., 2018). Another use of okra seeds flours dramatically increases the amount of extractable phenolics (EPP) and non-extractable hydrolysable phenolics (HPP) of wheat bread reaching up to 210.8 and $2944.8 \mathrm{mg} / 100 \mathrm{~g}$ of EPP and HPP respectively (Xu, et al., 2020).

\section{INBREEDING DEPRESSION AND HETEROSIS DESIGN IN OKRA}

The various studies of heterosis have been made by more researchers from India and all over the world to establish design of heterosis among several population, gene pool of okra and increases their hybrid developmental yield (Reddy, 2010). In germplasm a large variety present yet heterosis cross that is to be complete exploited through okra often reproduced and react well to asymmetry cross. Various breeders have verified the existence of different degree of asymmetry for yield in okra. Satisfactory result has been achieved in cumulative yield of okra through the successful manipulation of heterosis for pod and other desired traits. Many researchers have been extensively used dialele mating designs to generate single cross design and measure asymmetry in okra (Jindal, et al., 2009).

In Institute of Agricultural Sciences, BHU (Varanasi) the researchers recoded appreciable result of heterosis over better parents. The highest commercially cultivated varieties selection of best parents (IIVR 198 X Parbhani Kranti) for various horticulture and stranded heterosis during rainy season for number of fruits/ plant and the highly economic harvested varieties choose of best parents (EC 305612 X Pusa Sawani) for heterobeltiosis during summer season (Solankey et al., 2013). In Vegetable Research Station (Hyderabad) the researcher selected 10 homozygous lines of okra from germplasm and combination in all possible reciprocals to produced 45 hybrids (half dialele). The researchers found some best varieties (IC45732 X IC89976) crossed and the hybrid show good performance and found heterotic for pod yield $(7.17 \%$ and $15.22 \%$ result comparison to average to standard heterosis respectively) (Medagam et al., 2013). In Vegetable Research Farm BHU (Varanasi) the researchers using 5 lines and 3 testers by create 15 crosses. In this research as a based-on productivity level the researcher used highly significant and positive heterosis for total number of fruits/ plant and the Arka Abhay X Punjab Padmini (50.6\%) reveled the highest standard heterosis followed by VRO 6 X Parbhani Kranti (25.3\%) and Arka Abhay X Punjab Padmini (23.4\%) for number of fruits/ plant (Ashwani et al., 2013).

Devi et al., (2017) research was conducted to estimation the magnitude of heterosis for fruit yield and yield contributing characters in okra. In Swami Keshwanand Rajasthan 
Agricultural University, Bikaner the researchers used RBD with 3 replicates during kharif season. The most heterosis cross for commercially fruit yield/ plant and most of additional yield characters were found in Kashi Pragati $x$ Varsha Uphar, No. $315 \times$ Varsha Uphar, Kashi Pragati $\times$ Pusa A-4 and Hisar Naveen $\times$ Varsha Uphar. These crosses were considered promising for their use for yield improvement in okra.

The investigated by Kerure, P. and M. Pitchaimuthu, (2019) shown in okra was research the potential parents and better cross for 12 traits. The allover superior positive heterosis for total production/ plant was observed in cross IIHR875 X IIHR478 (168.55\%). The F1 hybrids highly productive commercial cultivation for late kharif season of Karnataka. The extent of positive heterosis crosses to various factors studied in okra and the comparison to simple to superior heterosis result was seen to be $62.12 \%$ and $44.11 \%$ respectively (Bhatt et al., 2016). The combination of capacity analysis show non-additive variance were increases to fruit productivity/ plant as extent and its input indicated the dominant character of non-additive gene action. Among cross JOK-2K-19 X AOL-13-73 show high SCA effects for fruit cultivation/ plant with desirable SCA effect for a number of fruits/ plant (Pithiya et al., 2020).

The experiment was placed in RBD with 3 replications. The experiment was found in $\mathrm{T} 7(30 \mathrm{~kg} \mathrm{Zn}+10 \mathrm{~kg} \mathrm{~B}) \mathrm{ha}-1$ combination may be helpful for okra cultivation in the field level to higher okra cultivation, whereas the control (T0) showed lowermost performance for the valued parameters. There hybrids were best performed in fruit cultivation/ plant and number of fruits/ plant (Jahan et al., 2020).

The study evaluated genetic diversity between morphoagronomic descriptors and okra landraces in Brazil based on AFLP markers and the preservation of Abelmoschus esculentus in gene banks is essential to the success of their use in reproductive programs. Genetic parameters confirmed the existence of accession, high accuracy and variability between the heredity index found for traits related to fruit and plant characters. Ward's group showed no connection between the groups formed with morphoagronomic, molecular data and the geographical origin of accession. No connection was seen between morphoagronomic descriptors and AFLP markers. Lack of correlation shows that both approaches to characterization are key to understanding and distinguishing okra accession (Massucato, et al., 2020).

\section{CONCLUSION}

The studies of okra as well as qualitative symptom in heterosis shows nutritive quality used for human health beneficial. The scientific experiments give some evidence to potential support the effect of components of okra in reduced risk for different diseases related to the role of okra's parts like fruits flowers, stems, etc. in disease prevention and mechanism of role only limited. Okra was imperative imperative that the scientific community remains to unravel mechanism involved in various disease prevention and determine how food from foods such as okra affect bioactive people health. Additional studies, the direct human health benefits of okra feeding need to be verified to provide comparable indication. Moreover, the okra can also be used an essential tool when it comes to less the change of starvation specially between resources- constrained rural household in addition to urban household. Okra consumption by both low- and high-income groups can also be change approach.

\section{ACKNOWLEDGEMENT}

The authors express their sincere gratitude Choudhary Charan Singh University Campus, Meerut-250004 (U.P.) India for their remarkable support.

\section{REFERENCES}

[1] Bhatt, J.P., Patel, N.A., Acharya, R.R. and Kathiria, K.B., 2016. Heterosis for yield and its related traits in Okra (Abelmoschus esculentus L. Moench). Electronic Journal of Plant Breeding, 7(1), pp.189-196.

[2] Birchler, J.A., Auger, D.L. and Riddle, N.C., 2003. In search of the molecular basis of heterosis. The Plant Cell, 15(10), pp. 2236-2239.

[3] Devi, S., Choudhary, B.R. and Verma, I.M., 2017. Heterosis for fruit yield and yield-contributing characters in okra (Abelmoschus esculentus). Current Horticulture, 5(2), pp.29-35.

[4] Dhankhar, B.S. and Mishra, J.P., 2005. Objectives of okra breeding. Journal of New Seeds, 6(2-3), pp.195-209.

[5] Diaz, F.A., Ortegon, M.A.S. and Loera, G.J., 1997. Fruit characteristics and yield of new okra hybrids. Subtropical Plant Science, 49, pp.8-11.

[6] Ewa C, Agnieszka G and Adametal F., 2011. The content of protein and of amino acids in Jerusalem artichoke tubers (Helianthus tuberosus L.) of red variety Rote Zonenkugel. Acta Scientiarum Polonorum. Technologia Alimentaria, 10(4):433-441

[7] FAOSTAT: Food and Agriculture Organization of the United Nations statistical database, available at: http://faosat.fao.org/, last access: 1 April 2011

[8] Gopalan, C., Rama Sastri, B.V. and Balasubramanian, S., 2007. Nutritive Value of Indian foods, published by National institute of Nutrition (NIN). ICMR (Indian Council of Medical Research).

[9] Holser, R.A. and Bost, G., 2004. Hybrid Hibiscus seed oil compositions. Journal of the American Oil Chemists' Society, 81(8), pp.795-797.

[10] Jahan, N., Hoque, M.A., Rasal-Monir, M., Fatima, S., Islam, M.N and Hossain, M.B., 2020. Effect of Zinc and Boron on Growth and Yield of Okra (Abelmoschus esculentus L.). Asian Journal of Advances in Agricultural Research, pp.41-47.

[11] Jindal, S. K., Arora, D. and Ghai, T. R. 2009. Heterobeltiosis and combining ability for earliness in okra (Abelmoschus esculentus (L.) Moench). Crop Improvement. 36 (2), 59-66.

[12] Kerure, P. and Pitchaimuthu, M., 2019. Evaluation for heterosis in okra (Abelmoschusesculentus L. Moench). Electronic Journal of Plant Breeding, 10(1), pp.248-255.

[13] Kumar, A., Baranwal, D.K., Aparna, J. and Srivastava, K., 2013. Combining Ability and heterosis for yield and its contributing characters in Okra (Abelmoschus esculantus (L.) Moench). Madras Agril. J, 100(1-3), pp.30-35.

[14] Madison, D., 2008. Renewing America's Food Traditions. Chelsea Green Publishing. p. 167.

[15] Maramag, R. P., 2013. Diuretic potential of Capsicum frutescens L., Corchorus oliturius L., and Abelmoschus esculentus L. Asian journal of natural and applied science, 2 (1). 60-69.

[16] Massucato, L.R., Nakamura, K.K., Ruas, P.M., Zeffa, D.M., Silva, D.J.H.D. and Gonçalves, L.S.A., 2020. Genetic diversity among Brazilian okra landraces detected by morphoagronomic and molecular descriptors. Acta Scientiarum. Agronomy, 42.

[17] MEF, (2013). Biology of Okra. Series of crop specific biology document. Ministry of Environmental and Forest Government of India. p1-8. 50.

[18] Moll, R.H. and Stuber, C.W., 1974. Quantitative geneticsempirical results relevant to plant breeding. In Advances in agronomy 26 , pp. 277-313. 
[19] Moyin-Jesu, E.I., 2007. Use of plant residues for improving soil fertility, pod nutrients, root growth and pod weight of okra (Abelmoschus esculentum L). Bioresource technology, 98(11), pp.2057-2064.

[20] National Research council. Okra lost crops of Africa. Vol. II Vegetables, 2006.

[21] Pandravada, S., 2004. Genetic analysis of early season cold tolerance in sorghum (Doctoral dissertation, Kansas State University).

[22] Petropoulos, S., Fernandes, Â., Barros, L. and Ferreira, I.C., 2018. Chemical composition, nutritional value and antioxidant properties of Mediterranean okra genotypes in relation to harvest stage. Food chemistry, 242, pp.466-474.

[23] Pithiya, D.J., Jethava, A.S., Zinzala, S.N. and Vachhani, J.H., 2020. Study on combining ability in okra [Abelmoschus esculentus (L.) Moench. IJCS, 8(1), pp.676-679.

[24] Reddy, M.T., 2010. Genetic diversity, heterosis, combining ability and stability in okra (Abelmoschus esculentus (L.) Moench). Unpublished PhD Thesis.

[25] Reddy, M.T., Babu, K.H., Ganesh, M., Reddy, K.C., Begum, H., Reddy, R.S.K. and Babu, J.D., 2013. Correlation and path coefficient analysis of quantitative characters in okra (Abelmoschus esculentus (L.) Moench). Songklanakarin Journal of Science \& Technology, 35(3).

[26] Ruberman, W., Weinblatt, E., Goldberg, J.D. and Chaudhary, B.S., 1984. Psychosocial influences on mortality after myocardial infarction. New England Journal of Medicine, 311(9), pp.552-559.

[27] Sahoo, P.K. and Srivastava, A.P., 2000. Development and performance evaluation of okra planter. Journal of Agricultural Engineering, 37(2), pp.15-25.

[28] Sanjeet, K., Dagnoko, S., Haougui, A., Ratnadass, A., Pasternak, D. and Kouame, C., 2010. Okra (Abelmoschus spp.) in West and Central Africa: potential and progress on its improvement. African Journal of Agricultural Research, 5(25), pp.3590-3598.

[29] Shukla, A., Pathak, S.C. and Agarwal, R.K., 1998. Field evaluation of okra varieties for resistance to shoot and fruit borer, Earias vittella (Fab.). Journal of Insect Science, 11(1), pp.60-61.

[30] Solankey, S.S., Singh, A.K. and Singh, R.K., 2013. Genetic expression of heterosis for yield and quality traits during different growing seasons in okra (Abelmoschus esculentus). Indian $\mathrm{J}$. Agric. Sci, 83(8), pp.17-21.

[31] Sorapong Benchasr, 2012. Okra (Abelmoschus esculentus (L.) Moench) as a valuable vegetable of the world. Ratarstvo $i$ povrtarstvo, 49(1), pp.105-112.

[32] Varmudy, V., 2011. Need to boost okra exports. Facts for You, 31(5), pp.21-23.

[33] Vijayraghvan, C. and Warier, V.A., 1946. Evolution of high yielding hybrid bhindi (Hibiscus esculentus L). In Proceeding of the Indian Science Congress (Vol. 33, p. 163).

[34] Xu, K., Guo, M., Roman, L., Pico, J. and Martinez, M.M., 2020. Okra seed and seedless pod: comparative study of their phenolics and carbohydrate fractions and their impact on bread-making. Food Chemistry, p.126387. 